\title{
Plant-disease experts blighted by red tape
}

Jonathan Knight, San Francisco

Concerns over homeland security have put US plant-disease scientists in the spotlight, and they're enjoying more money and greater visibility as a result. But the attendant bureaucracy and costly security measures already have some of them asking if all the attention is a blessing or a curse.

"It really has been a double-edged sword," says Jacqueline Fletcher, president of the American Phytopathological Society, which took up the issue at its annual meeting in Charlotte, North Carolina, this week.

Plant pathology has always been a poor relation of human health science, commanding only a tiny fraction of the government funding that biomedical research attracts. But since 11 September 2001, the people who study the blights, rusts, bacteria and viruses that attack plants have found themselves at the centre of a drive to protect America's food supply from potential terrorist acts. "There has been a greater understanding of plant pathology as something important to investigate," says Fletcher.

But with that visibility has come a growing concern about who has access to the pathogens under investigation. The Agricultural Bioterrorism Protection Act of 2002, passed last December, includes a list that was drawn up by the Animal and Plant Health Inspection Service (APHIS), of ten plant pathogens for which researchers must now undergo security checks if they are to continue studying them.

Although researchers recognize that stricter regulation is necessary, in certain cases it is doing more harm than good, says Caitilyn Allen, a plant pathologist at the University of Wisconsin, Madison. The

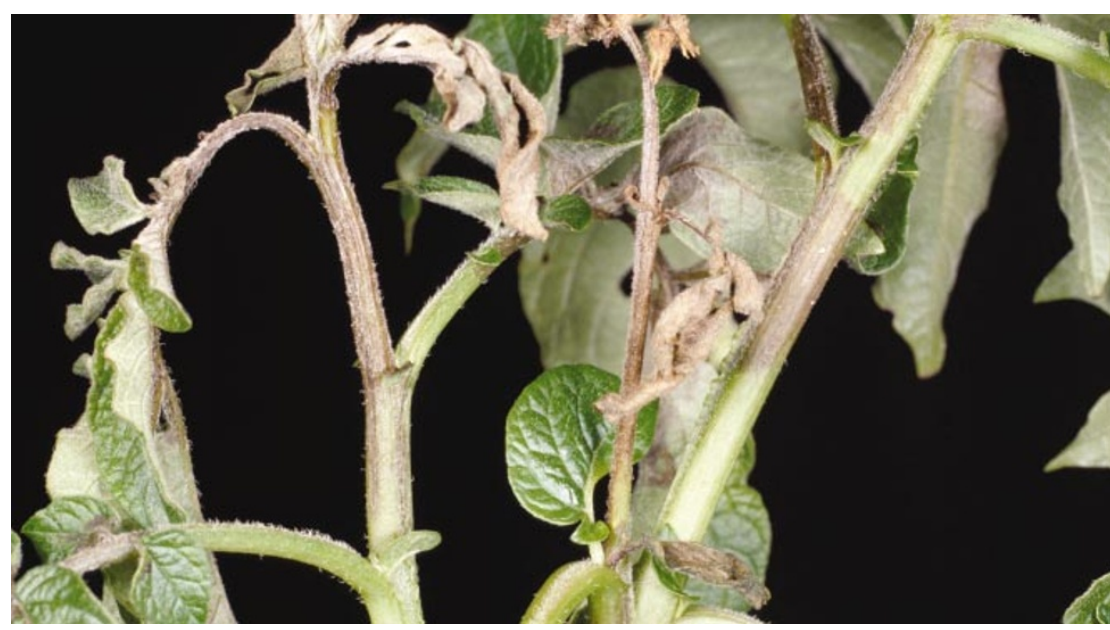

Green dilemma: could pathogens such as potato late blight prove to be dangerous in the wrong hands?

bacterium she studies, Ralstonia solanacearum, is on the APHIS list.

Although a major pest of potatoes in developing countries, Ralstonia is not a problem in North America, and Allen doubts it ever could be. It does poorly in northern climates, and has caused only minor losses in parts of Europe where it is endemic. It has also entered the United States several times via imported geraniums without consequence. "This is not the Ebola virus of the plant world," she points out.

Yet her university has spent $\$ 50,000$ adding locks and cameras to her lab to comply with the new security rules. The lab must also keep a continuous log of the amount of Ralstonia on hand, no easy task for an organism that doubles overnight. Although Allen has taken the trouble to comply, at least three of her colleagues at other universities have

\section{Gold-mine conversion eases closer}

\section{Geoff Brumfiel}

Officials in the state of South Dakota say that they have resolved a key liability issue that is blocking the conversion of the abandoned Homestake gold-mine into a deep underground laboratory.

Scientists want to convert the gold-mine, which is located near the city of Lead, into a state-of-the-art underground laboratory for studying neutrinos, rare physical processes, and geomicrobiology. But the mine's owner, Barrick Gold Corporation of Toronto, Canada, has refused to hand over the mine unless the company is indemnified against environmental liability (see Nature 415,105 ; 2002).

Last week, the South Dakota state government opened offices for the
Homestake Laboratory Conversion Project, which it hopes will eventually assume responsibility for the mine. The authority, among other things, plans to take out an insurance policy on the 127-year-old mine, alleviating the concerns of its current owners. "This authority will enable us to move ahead," says Richard Gowen, who heads the project from its main office in Rapid City.

Barrick spokesman Vince Borg says the company believes that the new proposal is a "likely route" for transferring the mine, and that the two sides are drawing up guidelines for donating the mine. But he adds that the handover will not take place unless the National Science Foundation approves funding for the project. not, she says, choosing instead to destroy their Ralstonia collections.

Jan Leach at Kansas State University in Manhattan, Kansas, says she nearly gave up working on the rice pathogen she studies, Xanthomonas oryzae pv. oryzicola, when it was listed by APHIS. She says existing that monitoring and inspection measures were sufficient. Not only are the nearest rice paddy-fields hundreds of miles away, but the disease causes only minor problems anyway.

One concern with the new requirements, says Leach, is that plant-disease labs will be less ready to respond when a new disease does arrive. At least two major crop diseases - the potato late blight (Phytophthora infestans) and the wheat infection karnal bunt (Tilletia indica) - have entered the United States since 1985, each prompting new research efforts.

Megan Thomas, a spokeswoman for APHIS, says the agency is planning to consult researchers and to re-evaluate the list annually, but she does not know when possible changes will be proposed.

Other researchers are starting to question whether there are elements of their research that they should not publish. In 1989, Martin Dickman of the University of Nebraska in Lincoln found that adding a single gene to a fungus that infects papaya through breaks in the skin gave it the ability to penetrate the fruit's skin on its own. Such work helps pathologists to understand what makes microbes virulent, but it could also in theory help terrorists to engineer nastier bugs. Asked if he would publish the finding today, he says: "I would have to think about it a lot harder."

Plant pathologists are not alone in facing these challenges, says Janet Shoemaker, director of public and scientific affairs for the American Society for Microbiology. After the anthrax attacks of 2001 there was a big push for new restrictions. "What we don't know yet is whether it has gone too far," she says. 